Available online at GSC Online Press Directory

GSC Biological and Pharmaceutical Sciences

e-ISSN: 2581-3250, CODEN (USA): GBPSC2

Journal homepage: https://www.gsconlinepress.com/journals/gscbps

(RESEARCH ARTICLE)

\title{
Antioxidants and hypoglycemic effect of some medicinal plants
}

\author{
Abubakar Asmau Niwoye *, Saidu Abubakar Ndaman, Akanya Helmina Olufunmilayo and Egwim Evans \\ Chidi
}

Department of Biochemistry, Federal University of Technology, Minna, Niger State, Nigeria.

Publication history: Received on 07 June 2019; revised on 23 July 2019; accepted on 26 July 2019

Article DOI: https://doi.org/10.30574/gscbps.2019.8.2.0124

\begin{abstract}
There is an increasing trend to replace synthetic drugs, which are of safety concern, with the natural remedies available from plant extracts. This study investigated the phytoconstituents as well as antioxidants and hypoglycemic effect of Anarcadium occidentales, Huntaria umbellata, Parkia biglobosa, Psidium guajava and Vitellaria paradoxa. Phytochemicals compositions were assayed using standard procedures. Antioxidant assays employed were ferric reducing antioxidant power and scavenging effect on the 1, 1-diphenyl-2-picrylhydrazyl radicals. Oral glucose tolerance test (OGTT) and amylase inhibitory assays were employed for hypoglycemic study. The concentration of phenols ranges from $184.368 \pm 0.23 \mathrm{mg} / \mathrm{g}$ (Anacardium occidentales) to $120.241 \pm 0.01 \mathrm{mg} / \mathrm{g}$ (Hunteria umbellata). However, Hunteria umbellata extract had the highest alkaloids $(76.76 \pm 0.01 \mathrm{mg} / \mathrm{g})$, Parkia biglobosa extract had the highest tanins $(137.55 \pm 0.05 \mathrm{mg} / \mathrm{g})$ while Vitellaria paradoxa extract had higher saponins $(188.50 \pm 0.01 \mathrm{mg} / \mathrm{g})$. Flavonoids was higher in Parkia biglobosa (458.06 $\pm 0.06 \mathrm{mg} / \mathrm{g}$ ) while Psidium guajava had the least. In DPPH assay A. occidentales extract had the lowest IC50 $(217.78 \pm 3.45 \mu \mathrm{g} / \mathrm{ml})$ comparable with the standards while $H$. umbellata had the highest (IC50 $=311.72 \pm 3.45 \mu \mathrm{g} / \mathrm{ml}$ ) and thus lowest activity. Anarcadium occidentales had higher $\alpha$-amylase inhibitory activity (IC50 $=171.13 \pm 0.14 \mu \mathrm{g} / \mathrm{ml}$ ) while Psidium guajava (IC50 $=304.64 \pm 0.14 \mu \mathrm{g} / \mathrm{ml}$ ) had the least activity. Oral glucose tolerance revealed the activities of the extracts in order of Anacardium occidentales $>$ Hunteria umbellata $>$ Vitellaria paradoxa $>$ Parkia biglobosa $>$ Psidium guajava. In conclusion, five medicinal plants investigated in this study possesses some antioxidants and hypoglycemic properties with Anacardium occidentales extract being the most potent, which may be attributed to their polyphenolic constituents.
\end{abstract}

Keywords: Phytochemicals; In vitro; Antioxidants; Hypoglycemic; Medicinal plants

\section{Introduction}

Diabetes mellitus (DM) is a group of metabolic disorder characterized by the alteration in metabolism of the major macromolecules (fat, proteins and carbohydrate) in response to loss of insulin sensitivity or insulin deficiency [1]. According to the recent update by World Health Organization, a total of about 150 million people are diabetic globally, and this is likely to scale up to 300 million by the end of 2022 . Also, about $9 \%$ of adult's population in 2014 were diabetic, of which 1.6 million cases were associated with deaths in 2016 [2]. The dilemma of diabetes complications also takes a great burden on global expenditure. The current drug therapies including biguanides, $\alpha$-glucosidase inhibitors, sulfonylureas and glinides are synthetic and are besieged with limitations in terms of cost, safety and efficacy [3].

Oxidative stress is very important because it unites the pathogenesis of all diabetic complications and indeed plays a role in all other aspects of diabetes pathology [4].According to the study carried out by Dokken et al., [5],a reactive oxygen species such as hydrogen peroxide, can cause a marked decrease in the insulin stimulation of the insulin signaling proteins like insulin receptor substrate (IRS) and protein kinase B (PKB) as well as glucose transport activity

\footnotetext{
${ }^{*}$ Corresponding author

E-mail address: niwoye.asmau@futminna.edu.ng
} 
thereby leading to insulin resistance. Another study also suggested that stress-activated serine kinases are involved in the pathogenesis of oxidant-induced insulin resistance and that excess mitochondrial $\mathrm{H}_{2} \mathrm{O}_{2}$ productions play a pivotal role in causing insulin resistance in the skeletal muscle of individuals with excess energy [6].

Since time immemorial, African medicinal plants have been used in folk medicine for the treatment of different diseases, which has been scientifically validated by different In vitro and in vivo studies [7-8]. Medicinal plants are known sources that have rich, yet unexploited potentials for anti-diabetic drugs. Thus, many of the synthetic drugs were discovered directly or indirectly from plant sources [9]. As a result, some natural products like herbs have been approved as new antioxidants and hypoglycemic agents, Although, there is need to identify novel substances that are safe, inexpensive and active towards free radicals and diabetes since most of the conventional drugs have undesirable side effect, expensive and loss of efficacy [10]. The present study therefore was aimed at evaluating the phytochemicals constituents, antioxidants and hypoglycemic effect of Anacardium occidentales, Hunteria umbellata, Parkia biglobosa, Psidium guajava and Vitellaria paradoxa.

\section{Material and methods}

\subsection{Sample collection}

Fresh leaves of Anacardium occidentales, Hunteria umbellate, Parkia biglobosa, Psidium guajava and Vitellaria paradoxa were collected between March and December, 2017 from Minna, Niger State, Nigeria. Authentication of the plants was done at the Herbarium Department of National Institute of Pharmaceutical Research and Development (NIPRD), Abuja Nigeria with the voucher numbers Anarcadium occidentaess (NIPRD/H/6870/) Parkia biglobosa (NIPRD/H/6868/) Vitellaria paradoxa (NIPRD/H/6867/) Psidium guaja (NIPRD/H/6869/) Huntaria umbellata(NIPRD/H/6871/).

\subsection{Experimental animal}

Healthy albino rats of average weight $(134.87 \pm 3.23)$ grams were obtained from animal holding unit, Federal University of Technology, Minna, Niger State Nigeria. The rats were maintained under standard laboratory condition. They were allowed access to rat pellets and water ad-libitum.

\subsection{Chemicals and reagent}

Alpha-amylase from Aspergillus oryzae was a product of Sigma-Adrich Co., St Louis, USA, while methanol was a product of Merck, Germany. Other chemicals and reagents were of analytical.

\subsection{Sample preparation and extraction}

The plants were thoroughly washed under running tap water and dried for 2 weeks at room temperature $37^{\circ} \mathrm{C} \pm 1$ and finally grinded by a milling machine. An aliquot 50 gof each of the plant material was extracted separately in $200 \mathrm{ml}$ of methanolusing Soxhlet apparatus and the resulting extract was concentrated using a rotary evaporator. The extracts were weighed and the percentage yield were calculated by using the formula below

$\%$ Yield $=$ Weight of the Crude Extract $(\mathrm{g}) \times 100$

Weight of Dried powdered sample (g) Tsado et al.,[11]

\subsection{Phytochemical analysis}

Qualitative and quantitative phytochemical analysis of crude methanol extract of the plants were carried out by standard methods [12-16].

\subsection{Antioxidant study}

Radical Scavenging ability of the crude extracts at varying concentrations was assayed by DPPH and FRAP methods described by Blois, [17] and Oyaizu et al., [18] respectively. Ascorbic acid and Gallic acid were used as the reference drug. 


\subsection{Alpha amylase inhibition assay}

Alpha-amylase inhibitory activities of the extract was determined at varying concentrations of the extract (62.5-500 $\mu \mathrm{g} / \mathrm{mL}$ ) using potato starch solution substrate as described byNickavar and Yousefian [19]. The $\alpha$-amylase inhibitory activity of the extract was calculated using the formula below [20].

$$
\text { The } \alpha \text { - amylase inhibitory activity }=\frac{[(A c+)-(A c-)]-[A s-A b)] \times 100}{[(A c+)-(A c-)]}
$$

Where, Ac+ = Absorbance of $100 \%$ enzyme activity (only solvent with enzyme).

Ac- = Absorbance at Zero \% (0 \%) enzyme activity (only solvent without enzyme).

As= Absorbance of test sample (with enzyme).

$\mathrm{Ab}=\mathrm{Absorbance}$ of blank (a test sample without enzyme).

\subsection{Oral glucose tolerance test (OGTT)}

Animals were fasted overnight for 12 hours and divided into groups of four rats each. The control group received 0.5 $\mathrm{ml}$ normal saline. The crude extracts groups was given $200 \mathrm{mg} \mathrm{kg} / \mathrm{bw}$ while the standard drug group received glibenclamide $(2.5 \mathrm{mg} / \mathrm{kg})$ All drugs were diluted with normal saline $(0.9 \%) \mathrm{Nacl}$ and administered orally by a garage. Glucose levels were measured before the rats received the treatment (zero time) and $30 \mathrm{~min}$ after glucose was administrated $(2 \mathrm{~g} / \mathrm{kg})$. Blood samples were collected from the tail vein at 30, 60, 90 and 120 minutes after glucose loading, and the glucose level (mg/dl) was assayed by a glucometer (Accu-Check®Performa).

\subsection{Statistical analysis}

Data were analyzed using Statistical analysis system (SAS) and presented as means \pm SEM. Comparisons between different groups were carried out by one way analysis of variance (ANOVA) followed by Duncan's Multiple Range Test (DMRT). The level of significance was set at $P<0.05$ [21].

\section{Results}

\subsection{Extracts yield}

The yield of the crude methanol extract of Anacardium occidentales, Hunteria umbellate Parkia biglobosa, Psidium guajava and Vitellaria paradoxa leaves are presented in Table 1. Hunteria umbellata leaf extract had the highest yield (31.50\%) while Parkia biglobosa leaf extract had the lowest yield (0.69\%).

Table 1 Crude methanol extract yield of the selected medicinal plants

\begin{tabular}{ll}
\hline Plant samples & Yield (\%) \\
\hline Anacardium occidentales & 25.33 \\
Hunteria umbellata & 31.50 \\
Parkia biglobosa & 20.69 \\
Psidium guajava & 26.60 \\
Vitellaria paradoxa & 27.77 \\
\hline
\end{tabular}

\subsection{Phytochemical composition of the selected plants}

The qualitative phytochemical constituents of the methanol leaf extracts of the selected plants are shown in Table 2 . Anthraquinones, flavonoids, tannins, steroids, alkaloids, glycosides, phenols, and saponins were detected. All the plants also had reducing sugars except in the leaf extract of Hunteria umbellata. Phlobatannins was not detected in all the extracts. The concentration of phenols ranges from $184.368 \pm 0.23 \mathrm{mg} / \mathrm{g}$ to $120.241 \pm 0.01 \mathrm{mg} / \mathrm{g}$ in Anacardium occidentales extract and Hunteria umbellata extract respectively (Table 3). Among the selected plants, Hunteria umbellata extract had the highest concentration of Alkaloids $(76.76 \pm 0.01 \mathrm{mg} / \mathrm{g})$ Parkia biglobosa extract had the highest 
tanins content $(137.55 \pm 0.05 \mathrm{mg} / \mathrm{g})$ and Vitellaria paradoxa extract contains more saponins $(188.50 \pm 0.01 \mathrm{mg} / \mathrm{g}) \mathrm{as}$ compared to other plant extracts. Flavonoids concentration was higher in Parkia biglobosa extract (458.06 $\pm 0.06 \mathrm{mg} / \mathrm{g}$ ) while Psidium guajava extracts had the lowest flavonoids content $(84.28 \pm 0.02 \mathrm{mg} / \mathrm{g})$.

Table 2 Qualitative phytochemical constituents of crude methanol leaf extract of some medicinal plant

\begin{tabular}{|c|c|c|c|c|c|}
\hline Phytochemicals & $\begin{array}{l}\text { Anacardium } \\
\text { occidentales }\end{array}$ & $\begin{array}{l}\text { Hunteria } \\
\text { umbellata }\end{array}$ & $\begin{array}{l}\text { Parkia } \\
\text { biglobasa }\end{array}$ & $\begin{array}{l}\text { Psidium } \\
\text { guajava }\end{array}$ & $\begin{array}{l}\text { Vitellaria } \\
\text { paradoxa }\end{array}$ \\
\hline Steroids & + & + & + & + & + \\
\hline Anthraquinones & + & + & + & + & + \\
\hline Flavonoids & + & + & + & + & + \\
\hline Tannins & + & + & + & + & + \\
\hline Alkaloids & + & + & + & + & + \\
\hline $\begin{array}{l}\text { Reducing } \\
\text { sugars }\end{array}$ & + & - & + & + & + \\
\hline Phlobatannins & - & - & - & - & - \\
\hline Glycosides & + & + & + & + & + \\
\hline Phenol & + & + & + & + & + \\
\hline Saponins & + & + & + & + & + \\
\hline
\end{tabular}

Table 3 Quantitative phytochemical constituents of crude methanol leaf extract some medicinal plant

\begin{tabular}{llllll}
\hline Plants & Phenols & Alkaloids & Tanins & Saponins & $\begin{array}{l}\text { (mg/g) } \\
\text { Flavonoids }\end{array}$ \\
\hline Anacardium occidentales & $184.36 \pm 0.23^{\mathrm{c}}$ & $65.50 \pm 0.02^{\mathrm{c}}$ & $110.20 \pm 0.50^{\mathrm{a}}$ & $85.00 \pm 0.01^{\mathrm{c}}$ & $58.50 \pm 0.02^{\mathrm{b}}$ \\
Hunteria umbellata & $120.24 \pm 0.01^{\mathrm{a}}$ & $76.76 \pm 0.01^{\mathrm{d}}$ & $101.53 \pm 0.01^{\mathrm{a}}$ & $65.32 \pm 0.00^{\mathrm{b}}$ & $24.59 \pm 0.01^{\mathrm{a}}$ \\
Parkia biglobosa & $151.20 \pm 0.05^{\mathrm{b}}$ & $75.65 \pm 0.03^{\mathrm{d}}$ & $137.55 \pm 0.05^{\mathrm{b}}$ & $62.24 \pm 0.05^{\mathrm{b}}$ & $458.06 \pm 0.06^{\mathrm{e}}$ \\
Psidium guajava & $167.33 \pm 0.01^{\mathrm{bc}}$ & $52.34 \pm 0.01^{\mathrm{b}}$ & $114.28 \pm 0.01^{\mathrm{a}}$ & $25.55 \pm 0.00^{\mathrm{a}}$ & $84.28 \pm 0.02^{\mathrm{c}}$ \\
Vitellaria paradoxa & $156.31 \pm 0.00^{\mathrm{b}}$ & $5.10 \pm 0.01^{\mathrm{a}}$ & $124.59 \pm 0.01^{\mathrm{ab}}$ & $188.50 \pm 0.01^{\mathrm{d}}$ & $125.84 \pm 0.03^{\mathrm{d}}$ \\
\hline \multicolumn{4}{c}{ Values are mean \pm SEM of 3 determinations. Values with different alphabets along a column are significantly different at $\mathrm{p}<0.05$}
\end{tabular}

\subsection{Alpha amylase inhibition}

The $\alpha$ - amylase inhibition of the extracts and their corresponding half maximal inhibitory concentration (IC 50 ) values are presented in Figures 1 and 2. The ability to inhibit $\alpha$ - amylase activity by the standard drug (acarbose) and the extracts increased with concentrations (62.5- $500 \mu \mathrm{g} / \mathrm{mL}$ ). At concentrations $62.5,125$, and $250 \mu \mathrm{g} / \mathrm{mL}$, acarbose had a significant $(\mathrm{p}<0.05)$ higher activity than all the extracts of the same concentration. But at $500 \mu \mathrm{g} / \mathrm{mL}$ the $\alpha$-amylase inhibitory activity of Parkia biglobosa extract was the same with acarbose. Amongst the extracts, the $\alpha$-amylase inhibitory activity of Parkia biglobosa, Huntaria umbellata and Anarcadium occidentales extracts were significantly $(\mathrm{p}<0.05)$ higher at various concentrations when compared to that Psidium guajava and Vitellaria paradoxa extracts.

Acarbose had a significantly ( $\mathrm{p}<0.05)$ higher activity and thus lower $\mathrm{IC}_{50}$ of $(76.34 \pm 0.12 \mu \mathrm{g} / \mathrm{ml})$ when compared to all the extracts. Parkia biglobosa (178.64 $\pm 0.98 \mu \mathrm{g} / \mathrm{ml})$, Huntaria umbellata $(199.13 \pm 0.18 \mu \mathrm{g} / \mathrm{ml})$ and Anarcadium occidentales $(171.13 \pm 0.14 \mu \mathrm{g} / \mathrm{ml})$ extracts had comparable IC 50 values but significantly lower and thus better activity than IC 50 value of Psidium guajava $(304.64 \pm 0.14 \mu \mathrm{g} / \mathrm{ml})$ and Vitellaria paradoxa $(224.95 \pm 0.14 \mu \mathrm{g} / \mathrm{ml})$ extracts. 


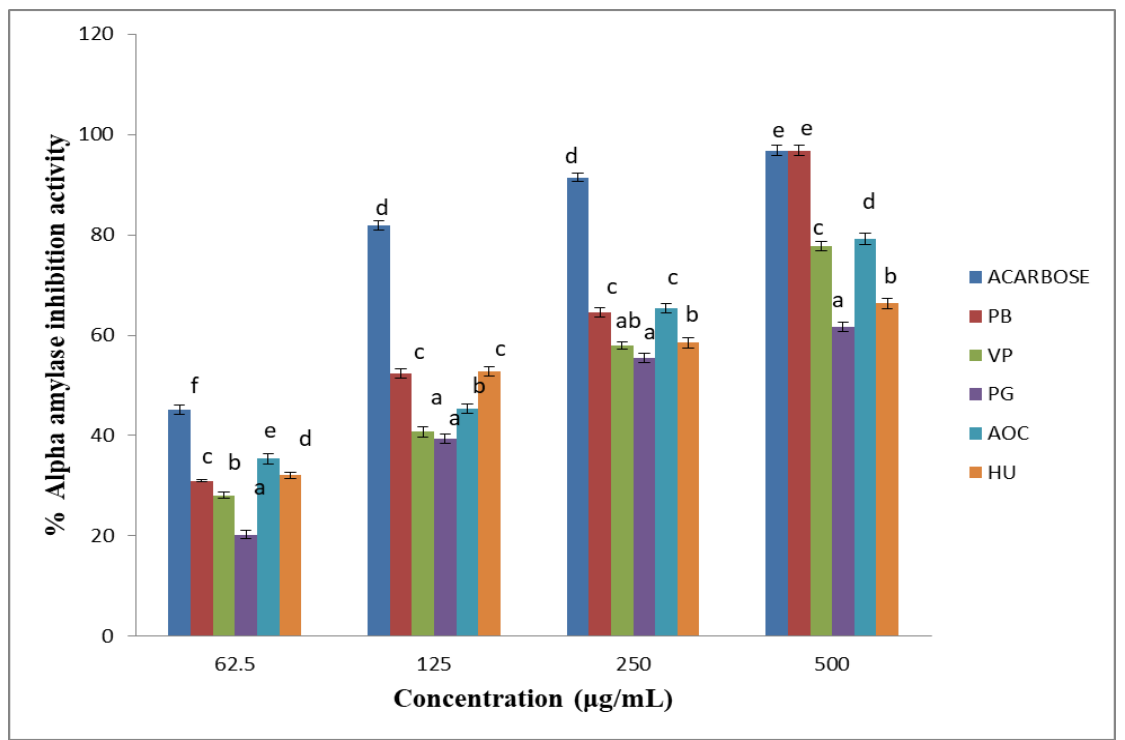

Figure 1 Effect of the some medicinal plant extracts on $\alpha$-amylase inhibition (AOC- Anacardium occidentales; HUHuntaria umbellate; PB- Parkia biglobosa, PG- Psidium guajava and VP: Vitellaria paradoxa).

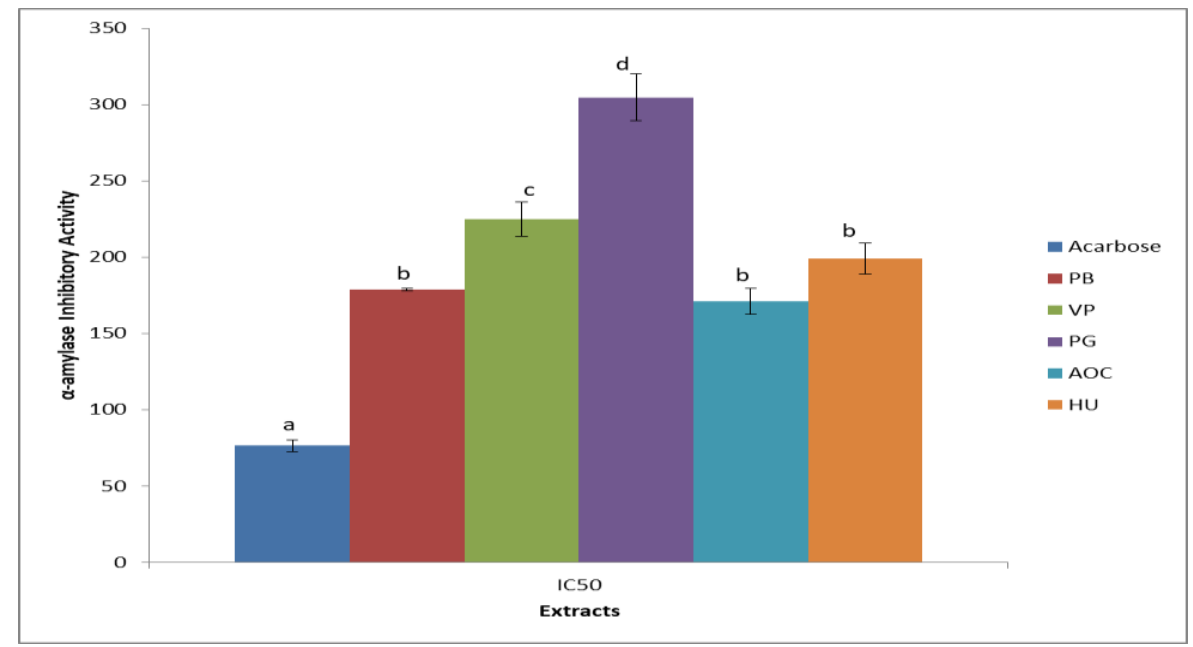

Figure 2 IC 50 of the plant Extracts on $\alpha$-amylase inhibition (AOC- Anacardium occidentales; HU- Huntaria umbellate; PB- Parkia biglobosa, PG- Psidium guajava and VP: Vitellaria paradoxa).

3.4. Antioxidant / DPPH radical scavenging activity of the crude methanol leaf extract of the selected plants.

Table 4 DPPH Radical scavenging activity of the crude methanol extracts of the selected plants

\begin{tabular}{llllllll}
\hline $\begin{array}{l}\text { Conc } \\
(\boldsymbol{\mu g} / \mathbf{m L})\end{array}$ & Gallic acid & $\begin{array}{l}\text { Ascorbic } \\
\text { acid }\end{array}$ & $\begin{array}{l}\text { Anacardium } \\
\text { occidentals }\end{array}$ & $\begin{array}{l}\text { Hunteria } \\
\text { umbellata }\end{array}$ & $\begin{array}{l}\text { Parkia } \\
\text { biglobosa }\end{array}$ & $\begin{array}{l}\text { Psidium } \\
\text { Guajava }\end{array}$ & $\begin{array}{l}\text { Vitalera } \\
\text { paradoxa }\end{array}$ \\
\hline 50 & $19.45 \pm 0.45^{\mathrm{a}}$ & $17.34 \pm 0.34^{\mathrm{a}}$ & $20.45 \pm 0.54^{\mathrm{a}}$ & $6.97 \pm 0.06^{\mathrm{a}}$ & $16.67 \pm 0.46^{\mathrm{a}}$ & $19.23 \pm 0.4^{\mathrm{a}}$ & $14.56 \pm 0.05^{\mathrm{a}}$ \\
100 & $32.76 \pm 0.36^{\mathrm{b}}$ & $30.34 \pm 0.32^{\mathrm{b}}$ & $35.56 \pm 0.21^{\mathrm{ab}}$ & $\begin{array}{l}19.24 \pm 0.31 \\
\mathrm{~b}\end{array}$ & $29.34 \pm 0.52^{\mathrm{b}}$ & $34.56 \pm 0.3^{\mathrm{b}}$ & $19.45 \pm 0.14^{\mathrm{a}}$ \\
200 & $57.34 \pm 0.67^{\mathrm{c}}$ & $61.23 \pm 0.98^{\mathrm{c}}$ & $59.43 \pm 0.53^{\mathrm{b}}$ & $\begin{array}{l}40.56 \pm 0.32 \\
\mathrm{c}\end{array}$ & $54.56 \pm 0.67^{\mathrm{c}}$ & $51.23 \pm 0.7^{\mathrm{c}}$ & $48.56 \pm 0.14^{\mathrm{b}}$ \\
400 & $78.89 \pm 0.29^{\mathrm{d}}$ & $75.66 \pm 1.04^{\mathrm{d}}$ & $69.45 \pm 0.21^{\mathrm{b}}$ & $\begin{array}{l}52.34 \pm 0.45 \\
{ }^{c}\end{array}$ & $77.34 \pm 0.38^{\mathrm{d}}$ & $74.56 \pm 0.3^{\mathrm{d}}$ & $69.34 \pm 0.21^{\mathrm{bc}}$ \\
500 & $87.46 \pm 0.56^{\mathrm{e}}$ & $88.56 \pm 0.45^{\mathrm{d}}$ & $86.75 \pm 0.36^{\mathrm{c}}$ & $84.56 \pm 0.54^{\mathrm{d}}$ & $85.14 \pm 0.62^{\mathrm{d}}$ & $85.67 \pm 1.4^{\mathrm{d}}$ & $83.66 \pm 2.45^{\mathrm{c}}$ \\
\hline \multicolumn{5}{c}{ Values are mean \pm SEM of 3 determinations. Values along the same column with different superscripts are significantly different $(\mathrm{p}<0.05)}$.
\end{tabular}


All the extracts and the standard antioxidants (Gallic acid and Ascorbic acid) at varying concentrations (50-500 $\mu \mathrm{g} / \mathrm{ml}$ ) demonstrated DPPH radical scavenging activities. They inhibited DPPH radical with increasing concentrations. $A$. occidentales extracts at concentrations 50,100, and $200 \mu \mathrm{g} / \mathrm{ml}$ exhibited more potent DPPH radical scavenging activity than other extracts but at $500 \mu \mathrm{g} / \mathrm{ml}$, all the extracts and standard antioxidants had comparable activities (Table 4). The concentration of the extracts that produce $50 \%$ inhibition $\left(\mathrm{IC}_{50}\right)$ of DPPH radicals of A. occidentales $(217.78 \pm 3.45$ $\mu \mathrm{g} / \mathrm{ml})$ extracts are lower than the values of ascorbic acid and gallic acid $(218.01 \pm 0.57 \mu \mathrm{g} / \mathrm{ml}$ and $219.66 \pm 0.97 \mu \mathrm{g} / \mathrm{ml})$ respectively but not significantly $(\mathrm{p}<0.05)$ different. However, H. umbellate extract had a significantly higher $(\mathrm{P}<0.05)$ IC $\mathrm{C}_{50}$ values $(311.72 \pm 3.45 \mu \mathrm{g} / \mathrm{ml})$ and consequently lower activity as compared to other extracts tested (Figure 3 ).

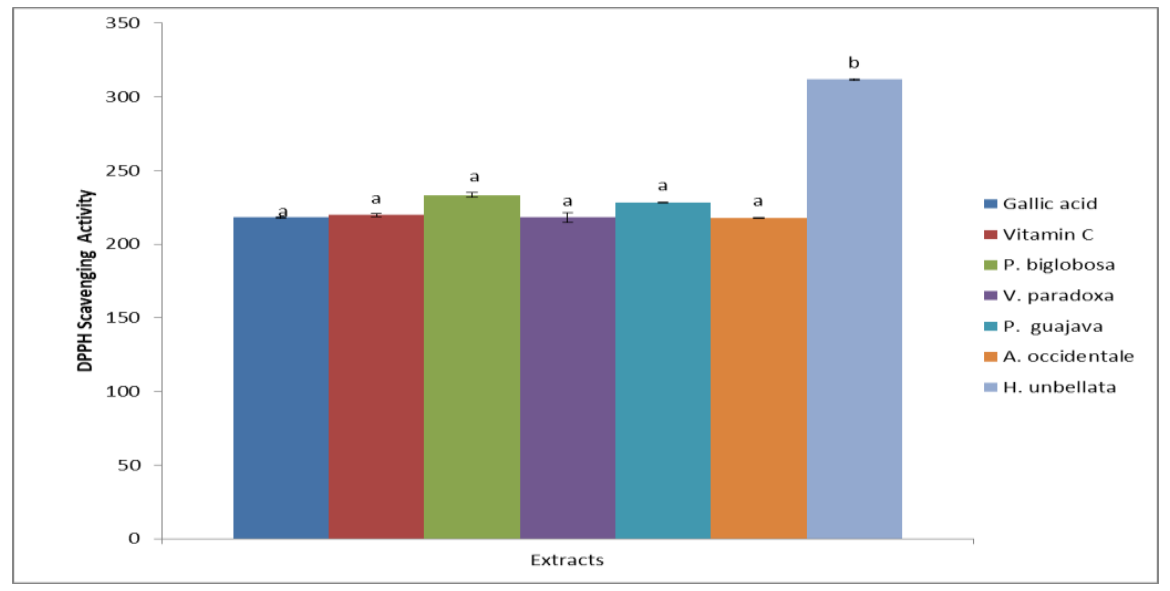

Figure 3 Inhibitory Concentration ( $\mathrm{IC}_{50}$ ) of methanol extract of the selected plants on DPPH radical scavenging activity

\subsection{Ferric reducing power activity (FRAP) of the crude methanol extracts}

The ferric reducing power activity of gallic acid and ascorbic acid increases steadily with increasing concentrations, however a dose independent activity was observed for all the extracts. Anacardium occidentales extract $(1.73 \pm 0.02)$ and Parkia biglobosa extract $(1.58 \pm 0.01)$ at $1000 \mu \mathrm{g} / \mathrm{ml}$ had significantly $(\mathrm{p}<0.05)$ higher \% inhibition than that of standards gallic acid $(1.23 \pm 0.01)$, ascorbic acid $(1.27 \pm 0.01)$ and the remaining extracts.

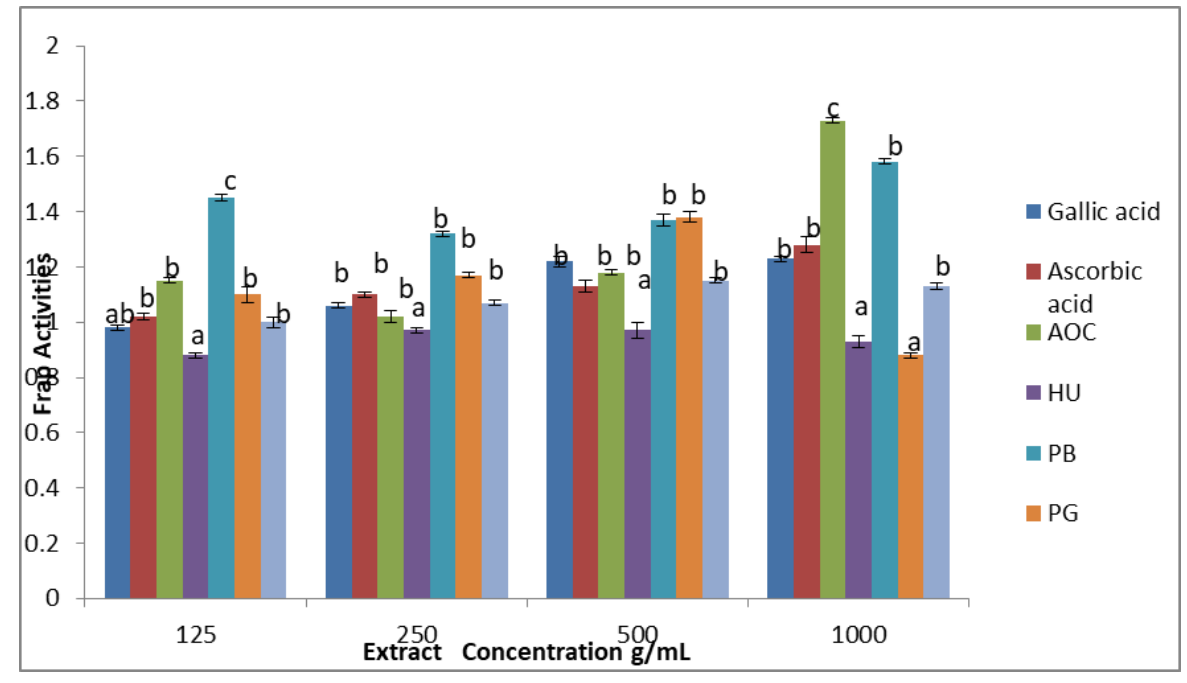

Figure 4 Ferric reducing power activity of the crude methanol extracts of the selected plants (AOC- Anacardium occidentales; HU- Huntaria umbellata; PB- Parkia biglobosa, PG- Psidium guajava and VP: Vitellaria paradoxa). 


\subsection{Oral glucose tolerance}

The plasma glucose concentration of the treated and normal rats reached hyperglycemic peak at 30 minutes after the oral administration of glucose and gradually decreased to the pre-prandial level. Anacardium occidentales extract produced plasma glucose levels significantly $(\mathrm{p}<0.05)$ lower than the group administered glibenclamide at 60,90 and 120 minutes after the glucose administration. The percentage glucose reduction of the extracts was in this order Anacardiumoccidentales $>$ Hunteriaumbellata $>$ Vitellariaparadoxa $>$ Parkiabiglobosa $>$ Psidiumguajava. Plasma glucose concentration of the normoglycemic rats showed the lowest as well as a time dependent decrease when compared with the groups administered extracts and glibenclamide. The rats not treated (negative control) had the highest plasma glucose concentration throughout the monitoring time with significantly $(\mathrm{p}<0.05)$ higher plasma glucose level when compared to normal and extract treated groups (Table 5).

Table 5 Effect of methanol leaf extracts of the selected plants on glucose tolerance in rats

\begin{tabular}{lllllll}
\hline Extracts & \multicolumn{5}{c}{ glucose concentration $(\mathbf{m g} / \mathbf{d L})$} \\
& $\mathbf{0}$ min & $\mathbf{3 0} \mathbf{~ m i n}$ & $\mathbf{6 0} \mathbf{~ m i n}$ & $\mathbf{9 0} \mathbf{~ m i n}$ & $\mathbf{1 2 0}$ min & $\begin{array}{l}\text { \% glucose } \\
\text { reduction }\end{array}$ \\
\hline AOC & $100.67 \pm 0.88^{\mathrm{b}}$ & $189.00 \pm 6.81^{\mathrm{d}}$ & $108.00 \pm 2.89^{\mathrm{a}}$ & $106.00 \pm 1.73^{\mathrm{a}}$ & $99.00 \pm 3.46^{\mathrm{b}}$ & $47.61 \%$ \\
HU & $89.67 \pm 2.40^{\mathrm{a}}$ & $178.33 \pm 7.13^{\mathrm{c}}$ & $130.67 \pm 4.33^{\mathrm{b}}$ & $105.00 \pm 4.04^{\mathrm{a}}$ & $100.67 \pm 2.60^{\mathrm{a}}$ & $43.54 \%$ \\
PB & $101.67 \pm 2.02^{\mathrm{b}}$ & $129.67 \pm 9.53^{\mathrm{ab}}$ & $139.00 \pm 8.08^{\mathrm{b}}$ & $102.00 \pm 1.16^{\mathrm{a}}$ & $96.00 \pm 2.31^{\mathrm{a}}$ & $25.58 \%$ \\
PG & $102.67 \pm 0.88^{\mathrm{b}}$ & $163.00 \pm 9.23^{\mathrm{bc}}$ & $127.00 \pm 0.58^{\mathrm{b}}$ & $107.67 \pm 1.45^{\mathrm{a}}$ & $104.67 \pm 3.17^{\mathrm{ab}}$ & $19.29 \%$ \\
VP & $97.00 \pm 5.77^{\mathrm{ab}}$ & $165.00 \pm 5.20^{\mathrm{bc}}$ & $134.00 \pm 4.04^{\mathrm{b}}$ & $107.00 \pm 2.89^{\mathrm{a}}$ & $107.67 \pm 2.60^{\mathrm{b}}$ & $34,74 \%$ \\
NC & $105.50 \pm 5.50^{\mathrm{b}}$ & $157.00 \pm 12.00^{\mathrm{b}}$ & $174.50 \pm 2.50^{\mathrm{c}}$ & $167.86 \pm 2.00^{\mathrm{b}}$ & $165.00 \pm 3.00^{\mathrm{c}}$ & $5.09 \%$ \\
STD & $92.67 \pm 0.89^{\mathrm{ab}}$ & $169.00 \pm 3.46^{\mathrm{bc}}$ & $139.00 \pm 6.35^{\mathrm{b}}$ & $117.00 \pm 1.15^{\mathrm{b}}$ & $104.67 \pm 3.76^{\mathrm{ab}}$ & $38.06 \%$ \\
Normal & $98.00 \pm 1.53^{\mathrm{ab}}$ & $95.67 \pm 2.96^{\mathrm{a}}$ & $96.33 \pm 3.17^{\mathrm{a}}$ & $95.67 \pm 2.03^{\mathrm{a}}$ & $94.33 \pm 2.03^{\mathrm{a}}$ & $1.40 \%$ \\
\hline
\end{tabular}

Values are Mean \pm SEM of triplicate determinations. Values with different alphabets along a column are significantly different at $\mathrm{p}<0.05$. AOCAnacardium occidentales; HU- Huntaria umbellata; PB- Parkia biglobosa; PG- Psidium guajava; VP-Vitellaria paradoxa; NC-Negative Control and STD- Glibenclamide.

\section{Discussion}

The medicinal importance of plants is due to the presence of some chemical substances in them. The presence of flavonoids in these plant extracts may have contributed to their hypoglycemic effect, many flavonoids due to their phenolic structure are antioxidants, and are known to be involved in the healing process of free radical-mediated diseases including diabetes [22-23]. The result obtained in the phytochemical screening of P. biglobosa seed as presented in Table 3, seems to justify the use of its seed for cardiac diseases as high number of flavonoids was found in them. This result is in agreement with the reports of Enujiugha, [24] that P. biglobosa plant are recognized to be very rich in phenolic compounds. However, the present study disagrees with the work of Ajaiyeoba [25] which indicated the absence of saponins and anthraquinones in the leaf extract of P. biglobosa. The differences in the phytochemical components of medicinal plant may account for the part of the plant used and solvent used in the extraction process.

Phenolic compounds have received considerable attention as protective factors against cancer and heart diseases because of their antioxidant potentials [26]. The higher concentration of phenols in Anacardium occidentales $(184.368 \pm 0.23 \mathrm{mg} / \mathrm{g})$ may be the rationale behind the use of Anacardium occidentales extract as antioxidants and anticancer agent as reported in different literatures. This is further buttressed by ability to protect the oxidation of lowdensity lipoprotein cholesterol, a major step in developing artherosclerosis and enhancement of antioxidant [27]

The presence of alkaloids in the crude methanol extracts of the plant under study probably gives credence to their hypoglycemic activity. Hunteria umbellata, parkia biglobosa and anarcadium occidentales extracts contained more alkaloids than vitellaria paradoxa and psidium guajava extracts. This finding correlate with the reports of [28] that Hunteria umbellata seed extracts had appreciable amount of alkaloids. Several other studies have also reported the presence of alkaloids in the stem bark and leaves of Parkia biglobosa and Anarcadium occidentales extracts [29]. It has 
been shown that medicinal plants with hypoglycemic and antidiabetic effect usually contain high concentration of alkaloids and flavonoids [30]

This present study has provided an empirical basis for the use of these plants in traditional medicinal practices. It is well documented in the literature that medicinal plants with hypoglycemic and antidiabetic effects usually contain high concentrations of alkaloids, flavonoids steroid glycosides [30-32]. Therefore, various composition of these important phytoconstients in these plants could justify their hypoglycemic action.

Alpha amylases are the carbohydrate metabolizing enzymes. The inhibition of this pancreatic alpha-amylase is an important therapeutic targets for delaying oligosaccharide digestion to absorbable monosaccharides in the intestinal brush border, resulting in reduced postprandial hyperglycemia [33].The significant inhibition of this enzyme by the five plant extracts evaluated in this study will therefore cause an increase in carbohydrate digestion time and reduces the glucose absorption [34]. By indication, this finding show that the plant extracts will be very useful in the control of glucose level by diabetic patient and also serve as alternative to chemical hypoglycemic agent such as acarbose and viglibose which are associated with various side effects like as diarrhoea, bloating dizziness and vomiting [35]

Psidium guajava efficiently inhibits alpha amylase enzyme in vitro in a dose dependent manner. This is in line with the finding of Manikandan et al., [36] who reported a dose-dependent increase in percentage inhibitory activity of alpha amylase enzyme by methanol seed of Psidium guajava, also Karthic et al. [37] reported that the aqueous extracts from Syzygium cumini seeds and Psidium guajava leaves also showed a dose dependent inhibitory effect on alpha-amylase activity. However, the higher $\mathrm{IC}_{50}$ of Psidium guajava when compared with standard drug (acarbose) and the remaining plants investigated in this study indicate its low alpha amylase inhibition potency as compared to other plants. However, this finding disagrees with earlier findings by Balasubramanian et al., [38], who reported that the ethyl acetate extract of Psidium guajava seed showed better alpha amylase inhibition than acarbose at higher concentration. Ramasamy et al., [39] also reported that the ethanolic extracts of P. guajava leaf extract have a high inhibitory activity on alpha amylase and alpha glucosidase enzymes than the aqueous extract of the same plant. The difference in activities reported could be attributed to the differences in the extracting solvents, as it has been affirmed that the phytochemical and bioactive agent in medicinal plant vary with the polarity of the solvent used in the extraction process.

As shown in Table 5, the significant $(\mathrm{p}<0.05)$ time related attenuation of the elevated post-absorptive blood glucose concentrations in the glibenclamide- and plant (Anacardium occidentales, Hunteria umbellata, Vitellaria paradoxa, Parkia biglobosa, Psidium guajava )-pretreated rats is suggestive that glibenclamide and plant extracts could be mediating their hypoglycaemic action via inhibition of intestinal glucose uptake, a mechanism which is similar to those of $\alpha$-glucosidase inhibitors (e.g. acarbose). The $60^{\text {th }}-120^{\text {th }}$ minutes postpandrial hypoglycaemia recorded in the distilled water-pretreated, glucose loaded rats could be due to the secondary effect of hyper insulinaemia following the glucose load. This is a well-established physiological response to hyperglycemia following a high glucose load or intake. The $25.58 \%$ decrease in blood glucose level of glucose-loaded rats following $2 \mathrm{hrs}$ (120 minutes) pre-treatment with $P$. biglobosa extract correspond adequately with the previous study by Fred-Jaiyesimi and Abo [40] who reported that $P$. biglobosa seed methanol extract administered to the glucose-loaded diabetic rats exhibited a decrease in the blood glucose levels of the animals throughout the period of the study, with a peak decrease in blood glucose level of $64 \%$ at $5 \mathrm{hr}$. The higher activity demonstrated by the Anacardium occidentales as compared to the remaining plant could be justified by its significant $(\mathrm{p}<0.05)$ higher contents of phenol $(184.368 \pm 0.23 \mathrm{mg} / \mathrm{g})$ and saponins $(85.00 \pm 0.01 \mathrm{mg} / \mathrm{g})$. In the same trend the lower activities of Psidium guajava also correspond with it significant $(\mathrm{p}<0.05)$ lower saponin contents $(2.55 \pm 0.00 \mathrm{mg} / \mathrm{g})$. Literatures has shown that extracts with high triterpenoid saponins and phenol content mediate their hypoglycaemic effect via inhibition of intestinal glucose uptake, increased hepatic glucose deposition and enhanced hyper insulinaemia [27]. It is therefore reasonable to assume that the saponins contained in these plant extracts is responsible for the observed attenuation in the post absorptive glucose concentration.

There is increasing interest in deleterious role of free radicals and preventive/ protective properties of natural products against oxidation processes [26]. In the present study, methanol extract of the plant investigated, particularly, the $A$. occidentales promoted an inhibition of DPPH radical and the transformation of $\mathrm{Fe}^{3+}$ to $\mathrm{Fe}^{2+}$ in a similar trend to that of the standard drugs. The Lower IC50 recorded for A. occidentalis is an indication of it higher antioxidants activities compared with other plants, thus this plant could be considered as a natural source of antioxidants. Thetotal phenolic and total flavonoid contents of the extracts recorded in this study could be responsible for the observed free radical scavenging activity of the plant extract. The $\mathrm{IC}_{50}$ reported for the five medicinal plants in this study were however, higher than $52.45 \pm 3.05 \mu \mathrm{g} / \mathrm{mL}$ reported for X. aethiopica [41], but lower than $263.53 \mathrm{mg} / \mathrm{mL}$ reported for Phyllanthus [42], $263.53 \pm 3.24 \mathrm{mg} / \mathrm{mL}$ reported for Senna ocidentalis [43], C. adansonii $(1562.52 \mathrm{mg} / \mathrm{mL})$ and N. laevis $(155.17 \mathrm{mg} / \mathrm{mL})$ [44]. This differences could be explained by the findings from previous studies, who reported that bioactive metabolites 
in medicinal plants varies with the type of plants, part of the plants, duration of sample collections and also the differences in the solvents uses in extraction process [45].This is also supported by the absence of phlobatannins in the plants investigated in this study.

\section{Conclusion}

The medicinal plants investigated in this study had antioxidants and hypoglycemic properties with Anacardium occidentales being the most potent, this could be attributed to their polyphenolic constituents.

\section{Compliance with ethical standards}

\section{Acknowledgments}

The authors wish to thank Tertiary Education Trust Fund (Tetfund) Nigeria for funding this research, Centre for Genetic engineering and Biotechnology and Department of Biochemistry Federal University of Technology Minna for providing the enabling environment.

\section{Disclosure of conflict of interest}

The authors declare that they have no conflict of interest.

\section{Statement of ethical approval}

The principles governing the use of laboratory animals as laid out by the Federal University of Technology, Minna Committee on Ethics for Medical and Scientific Research and also existing internationally accepted principles for laboratory animal use and care as contained in the Canadian Council on Animal Care Guidelines and Protocol Review were duly observed.

\section{References}

[1] Belayneh and YBirru, EM. (2018). Anti-diabetic activities of hydromethanolic leaf extract of Calpurnia aurea (Ait) Benth Subspecies aurea (Fabaceae) in Mice. Hindawi Evidence-Based Complementary Alternative Medicine, Article ID 3509073, 9.

[2] World Health Organisation Global estimates of the prevalence of diabetes for 2017 Diabetes WHO fact sheet Geneva, Switzerl, 2018.

[3] Omonije 00, Saidu AN and Muhammad HL. (2019). Anti-diabetic activities of Chromolaena odorata methanol root extract and its attenuation effect on diabetic induced hepatorenal impairments in rats. Clinical Phytoscience International Journal of Phytomedicine and Phytotherapy, 5-23,

[4] Ibrahim MA, Koorbanally NA, Kiplimo JJ and Islam MS. (2012). Anti-oxidative activities of the various extracts of stem bark, root leaves of Ziziphus mucronata (Rhamnaceae) in vitro. Journal of Medicinal Plant Research, 6(25), 4176-4184.

[5] Dokken BB, Saengsirisuwan V, Kim JS, Teachey MK and Henriksen EJ. (2008). Oxidative stress-induced insulin resistance in skeletal muscle: role of glycogen synthase kinase-3. American Journal of Physiology Endocrinology Metabolism, 294, 615-621.

[6] Henriksen EJ, Diamond-Stanic MK and Marchionne EM. (2011). Oxidative stress the etiology of insulin resistance type 2 diabetes. Free Radical Biol Med, 51, 993-999.

[7] Lawal B, Shittu OK, Kabiru AY, Jigam AA, Umar MB, Berinyuy EB and Alozieuwa BU. (2015). Potential antimalarials from African natural products: A review. J Intercult Ethnopharmacology, 4(4), 318-343.

[8] Umar SI, Ndako M, Jigam AA, Adefolalu SF, Ibikunle GF, Lawal B. (2019). Anti-plasmodial, Anti-inflammatory, antinociceptive and safety profile of Maytenus senegalensis root bark extract on hepato-renal integrity in experimental animals. Comparative Clinical Pathology, 1-9.

[9] Swaroopa P and Code QR. (2017). Review on antidiabetic activity on medicinal plants. Iran journal of pharmaceutical Research, 7(12). 
[10] Yusuf AA, Lawal B, Yusuf MA, Omonije YO, Adejoke AA, Raji FH and Wenawo DL. (2018). Free radical scavenging, antimicrobial activities effect of sub-acute exposure to Nigerian Xylopia Aethiopica seed extract on liver kidney functional indices of albino rat. Iranian journal of toxicology, 12 (3), 51-58.

[11] Tsado AN, Lawal B, Mohammed SS, Famous IO, Yahaya AM, Shu'aibu M and Caleb T. (2015). Phytochemical composition antimalarial activity of methanol leaf extract of Crateva adansonii in Pberghei infected mice. British Biotechnology Journal 6(4), 165-173.

[12] Trease GE and Evans WC. (1983). Textbook of Pharmacognosy 12th Edn, Bailliere Tindall, London.

[13] Sofowora A. (1996). Medicinal plants traditional medicines in Africa. Spectrum Books LTD, Sunshine House 1, Emmanuel Alayade Street, PMB 5612, Ibadan, Nigeria.

[14] Harborne JB. (1998). Phytochemical methods: A guide to modern technique of plant analysis. 3 ${ }^{\text {rd }}$ Edn, Springer, London, ISBN: 9780412572708, 88-185.

[15] Chang CC, Yang MH, Wen HM and Chern JC. (2002). Estimation of total flavonoid content in propolis by two complementary colometric methods. Journal of Food Drug Analysis, 10(3), 178-182.

[16] Oloyed OI. (2005). Chemical profile of unripe pulp of Carica papaya. Pakistan Journal of Nutrition, 4, $379-381$.

[17] Blois MS. (1958). Antioxidant determinations by the use of a stable free radical Nature, 181, (4617), 1199-1200.

[18] Oyaizu M. (1986). Studies on products of browning reaction-antioxidative activities of products of browning reaction prepared from glucosamine. Japan Journal of Nutrition, 44, 307-315.

[19] Nickavar B and Yousefian N. (2009) Inhibitory effects of six Allium species on $\alpha$-amylase enzyme activity. Iranian Journal of Pharmacology Research 8, 53-57.

[20] Hansawasdi C, Kawabata J and Kasai T. (2006). $\alpha$ - amylase inhibitors from Roselle (Hibiscus sabdariffa Linn) tea Bioscience Biotechnology Biochemistry, 64, 1041-3.

[21] SAS Statistical analysis system, SAS users guide: statistics Cary: SAS institute Inc; 2008.

[22] Carini M, Adlini G, Furlanetto S, Stefani R and Facino RM. (2001). LC coupled to ion- trap MS for the rapid screening detection of polyphenol antioxidant from Helichrysum stoechas. J Pharm Biomed Anal 24, 517-526.

[23] Saidu AN, Abubakar AN, Daniel MU and Kabiru AY. (2014). Phytochemical screening effects of methanolic extract of Azadirachta indica Leaf in alloxan induced diabetic rats. IOSR Journal of Pharmacy Biological Sciences 9(1), 1620 .

[24] Enujiugha VN. (2010). The antioxidant free radical scavenging capacity of phenolics from african locust bean seeds (Parkia biglobosa) Advances in food sciences 32(2), 88-93.

[25] Ajaiyeoba EO. (2002). Phytochemical Antibacterial Properties Of Parkia Biglobosa Parkia Bicolor Leaf Extracts Afr J Biomed Res Vol 5, 125 - 129.

[26] Lawal B, Shittu OK, Oibiokpa FI, Berinyuy EB and Muhammed H. (2016). African natural products with potential antioxidants hepatoprotectives properties: A review. Clinical Phytoscience, 2(23), 1-66.

[27] Shane-McWhorter L. (2001). Biological complementary therapies: a focus on botanical products in diabetes. Diabetes Spectrum 14, 199 - 208.

[28] Adeneye AA, Adeyemi 00, Agbaje EO and Sofidiya MO. (2012). The novel antihyperglycaemic action of Hunteria umbellata seed fractions mediated via intestinal glucose uptake inhibition. African Journal of Traditional Complementary Alternative Medicine, 9(1), 17-24.

[29] Builders M, Wannang N and Aguiyi J. (2011). Antiplasmodial activities of Parkia biglobosa leaves: In vivo and in vitro studies. Annual Biology Research, 2, 8-20.

[30] Oladele SM, Ayo JO and Adaudi AO. (1995). Medicinal physiological properties of flavonoids, coumarin derivatives anthraquinones of plants origin. West African J Pharmacol Drug Res, 11, 134-144.

[31] Sharma B, Balomajumder C and Roy P. (2008). Hypoglycaemic hypolipidaemic effects of flavonoid rich extract from Eugenia jambolana seeds on streptozotocin induced diabetic rats. Food Chemical Toxicology, 46(7), 2376 2383.

[32] Adallu B and Radhika B. (2000). Hypoglycaemic, diuretic hypocholesterolaemic effect of winter cherry (Winthania somnifera, Dunal) root. Indian Journal of Experimental Biology, 38, 607 - 609. 
[33] Sunday 00, Blessing 00, Ifeoma II, Princemartins EO, Roger MC and Olayinka AA. (2017). Alpha-amylase inhibition antioxidative capacity of some antidiabetic plants used by the traditional healers in South eastern Nigeria. Scientific World Journal Article ID 3592491, 11.

[34] Cheng AYY and Fantus IG. (2005). Oral antihyperglycemic therapy for type 2 diabetes mellitus. Canadian Medicinal Association Journal, 172(2), 213-226.

[35] Laha S and Paul S. (2019). Gymnema sylvestre (Gurmar): A potent herb with anti-diabetic antioxidant potential. Pharmacog J, 11(2), 201-6.

[36] Manikan R, Vijaya A and Muthumani GD. (2013). Phytochemical in vitro anti-diabetic activity of methanolic extract of Psidium guajava leaves. Int J Curr Microbiol App Sci, 2(2), 15-19.

[37] Karthic K, Kirthiram KS, Sasassivam S and Thayumanavan B. (2008). Identification of $\alpha$-amylase inhibitors from Syzygium cumiini Linn seed. Indian journal of experimental biology, 6, 677-680.

[38] Balasubramanian S, Nancy V, Rajesh KR, Saraswathi G and Sowmya M. (2015). Phytochemical pharmacological evaluation of seeds of Psidium guajava Linn. Annals of Biological Research, 2015, 6 (9), 29-35.

[39] Ramasamy M, Arumugam VA, Sampath K and Pushpa K. (2016). Phytochemical in vitro antidiabetic activity of Psidium guajava leaves. Pharmacognosy Journal, 8(4), 392-394.

[40] Fred-Jaiyesimi AA and Abo KA. (2009). Hypoglycaemic effects of Parkia biglobosa (Jacq) Benth seed extract in glucose-loaded NIDDM rats. Int J Biol Chem Sci, 3(3), 545-550.

[41] Yusuf AA, Lawal B, Abubakar AN, Berinyuy EB, Omonije YO, Umar SI, Shebe MN and Alhaji YM. (2018). In-vitro antioxidants, antimicrobial toxicological evaluation of Nigerian Zingiber officinale. Clinical Phytoscience, 4(12), $1-8$.

[42] Ibrahim AM, Lawal B, Abubakar AN, Tsado NA, Kontagora GN, Gboke GA and Berinyuy EB. (2017). Antimicrobial free radical scavenging potentials of n-hexane ethyl acetate fractions of Phyllanthus fraternus. Nigerian Journal of Basic Applied Science, 25(2), 06-11.

[43] Tsado NA, Lawal B, Kontagora GN, Muhammad BM, Yahaya MA, Gboke JA Muhammad UA and Hassan MK. (2016). Antioxidants antimicrobial- activities of methanol leaf extract of Senna occidentalis. Journal of Advances in Medical Pharmaceutical Sciences, 8(2), 1-7.

[44] Tsado A, Ndarubu LB, Ossai PC, Jagaba A, Gwadabe NK, Jiya AG, Umar AM and Oladunjoye JOl. (2016). Antioxidants antimicrobial activities of methanol extract of Newbouldia laevis Crateva adansonii. Journal of Pharmacy Allied Health Sciences, 6, 14-19.

[45] Lawal B, Ossai PC, Shittu OK and Abubakar AN. (2014). Evaluation of phytochemicals, proximate, minerals antinutritional compositions of Yam peel, Maize chaff bean coat. International Journal of Applied Biological Research. 6(2), 01-17.

\section{How to cite this article}

Abubakar AN, Saidu AN, Akanya HO and Egwim EC. (2019). Antioxidants and hypoglycemic effect of some medicinal plants. GSC Biological and Pharmaceutical Sciences, 8(2), 70-80. 